Article

\title{
Salivary Glands after Prolonged Aluminum Exposure: Proteomic Approach Underlying Biochemical and Morphological Impairments in Rats
}

\author{
Deiweson Souza-Monteiro ${ }^{1,+}$, Márcia Cristina dos Santos Guerra ${ }^{1,+}$, Leonardo Oliveira Bittencourt ${ }^{1}$, \\ Walessa Alana Bragança Aragão ${ }^{1} \mathbb{D}$, Aline Dionizio ${ }^{2}$, Felipe Martins Silveira ${ }^{3} \mathbb{D}_{\text {, }}$ \\ Marília Afonso Rebelo Buzalaf ${ }^{2}$ (D), Manoela Domingues Martins ${ }^{3}$, Maria Elena Crespo-Lopez ${ }^{4}$ (D) \\ and Rafael Rodrigues Lima ${ }^{1, *(\mathbb{D})}$
}

check for updates

Citation: Souza-Monteiro, D.; Guerra M.C.d.S.; Bittencourt, L.O.; Aragão, W.A.B.; Dionizio, A.; Silveira, F.M.; Buzalaf, M.A.R.; Martins, M.D.; Crespo-Lopez, M.E.; Lima, R.R. Salivary Glands after Prolonged Aluminum Exposure: Proteomic Approach Underlying Biochemical and Morphological Impairments in Rats. Int. J. Mol. Sci. 2022, 23, 2251. https://doi.org/10.3390/ ijms23042251

Academic Editor: Narasimham

L. Parinandi

Received: 29 December 2021

Accepted: 18 January 2022

Published: 18 February 2022

Publisher's Note: MDPI stays neutral with regard to jurisdictional claims in published maps and institutional affiliations.

Copyright: (C) 2022 by the authors. Licensee MDPI, Basel, Switzerland. This article is an open access article distributed under the terms and conditions of the Creative Commons Attribution (CC BY) license (https:// creativecommons.org/licenses/by/ $4.0 /)$
1 Laboratory of Functional and Structural Biology, Biological Sciences Institute, Federal University of Pará, Belém 66075-110, Brazil; deiweson.monteiro@gmail.com (D.S.-M.); marciacsguerra@gmail.com (M.C.d.S.G.); leo.bittencourt25@gmail.com (L.O.B.); walessa.aragao@gmail.com (W.A.B.A.)

2 Department of Biological Sciences, Bauru School of Dentistry, University of São Paulo, Bauru 17012-901, Brazil; alinesdionizio@usp.br (A.D.); mbuzalaf@fob.usp.br (M.A.R.B.)

3 Faculty of Department of Oral Pathology, School of Dentistry, Federal University of Rio Grande do Sul, Porto Alegre 90040-060, Brazil; fp.martinss@gmail.com (F.M.S.); manomartins@gmail.com (M.D.M.)

4 Laboratory of Molecular Pharmacology, Institute of Biological Sciences, Federal University of Pará, Belém 66075-110, Brazil; maria.elena.crespo.lopez@gmail.com

* Correspondence: rafalima@ufpa.br

$\dagger$ The authors contributed equally to this work.

\begin{abstract}
Aluminum ( $\mathrm{Al})$ is one of the most abundant elements on Earth, and its high extraction rate and industrial use make human exposure very common. As Al may be a human toxicant, it is important to investigate the effects of $\mathrm{Al}$ exposure, mainly at low doses and for prolonged periods, by simulating human exposure. This work aimed to study the effects of low-dose exposure to chloride aluminum $\left(\mathrm{AlCl}_{3}\right)$ on the oxidative biochemistry, proteomic profile, and morphology of the major salivary glands. Wistar male rats were exposed to $8.3 \mathrm{mg} / \mathrm{kg} /$ day of $\mathrm{AlCl}_{3}$ via intragastric gavage for 60 days. Then, the parotid and submandibular glands were subjected to biochemical assays, proteomic evaluation, and histological analysis. Al caused oxidative imbalance in both salivary glands. Dysregulation of protein expression, mainly of those related to cytoarchitecture, energy metabolism and glandular function, was detected in both salivary glands. Al also promoted histological alterations, such as acinar atrophy and an increase in parenchymal tissue. Prolonged exposure to $\mathrm{Al}$, even at low doses, was able to modulate molecular alterations associated with morphological impairments in the salivary glands of rats. From this perspective, prolonged $\mathrm{Al}$ exposure may be a risk to exposed populations and their oral health.
\end{abstract}

Keywords: aluminum; salivary glands; oxidative stress; proteomic; morphology; toxicology; intoxication

\section{Introduction}

Aluminum (Al) is an element that is widely distributed in the Earth's crust and is of great environmental importance because of its excellent physical properties; thus, it is used by industries at large scales [1]. The metallic form of $\mathrm{Al}$ is not directly found in soil, so its extraction is dependent on the mining of Bauxite, which is the primary mineral source of Al $[2,3]$.

Humans are exposed to Al by drug consumption, cosmetics, food, and Al-enriched water [4-6]. The presence of residual Al in drinking water is one of the most common forms of exposure to the metal [7] and studies indicate that Al can enter the human body through a combination of $\mathrm{Al}$ ions with other molecules, forming aluminum salts that can be easily absorbed in the stomach $[8,9]$. Then, $\mathrm{Al}$ is distributed throughout the organism 
and can affect many organs, such as the cerebellum [10], kidneys [11] and even the salivary glands [12] of animals.

Salivary glands are important components of the stomatognathic system since they synthesize and excrete saliva. Saliva performs several functions: protection and lubrication of the oral tissues, initiation of digestion, exertion of antibacterial effects, tissue repair, and buffering [13]. Malfunction of the salivary glands can interfere with oral homeostasis by altering the quality and quantity of saliva, which can cause or aggravate several disorders, such as xerostomia and periodontal disease [14,15]. Studies from our group have already shown that salivary glands are susceptible to injury caused by exposure to metals, such as mercury, lead, and even $\mathrm{Al}$ [16-22].

In previous studies from our group, we showed $\mathrm{Al}$ deposition in the salivary glands [12] and also oxidative stress and morphology impairment after low-dose exposure to $\mathrm{Al}$ [22]. However, little is known about the mechanisms related to the effects of chronic and lowdose $\mathrm{Al}$ exposure, especially the changes related to molecular impairments.

From this perspective, this study aimed to investigate the effects of low-dose and long-term exposure to $\mathrm{Al}$, in the salivary glands of rats, as a means of simulating human exposure. Our study evaluated the possibility of oxidative imbalance and its association with the modulation of the proteomic profile and impairments in the morphology of the two main pairs of major salivary glands after chronic $\mathrm{Al}$ exposure.

\section{Results}

\subsection{Al Triggered Biochemical Changes Related to Redox Homeostasis in the Salivary Glands} of Rats

For this parameter, the antioxidant capacity against peroxyl radicals (ACAP) was tested, in which the ROS levels in the samples were measured. These were subjected to two readings in a fluorimeter: samples that received the addition of a peroxyl radical generator and samples without this addition (blank samples). Total fluorescence over time was fitted to a polynomial function that generated area graphs with and without radical generation. The relative area was quantified and for better expression of the data in bar graphs, the inverse of the relative area was used. Therefore, our results show that exposure to $\mathrm{Al}$ reduced the ACAP in the parotid glands (aluminum chloride $\left(\mathrm{AlCl}_{3}\right): 57.79 \pm 5.73 \%$; control: $100 \pm 8.99 \%, p=0.0019)$ and in the submandibular glands $\left(\mathrm{AlCl}_{3}: 36.9 \pm 7.94 \%\right.$; control: $100 \pm 8.17 \%, p=0.0001$ ) (Figure $1 \mathrm{~A}$ ).

In addition, the lipid peroxidation (LPO) assay was performed, where the levels of the malondialdehyde (MDA) metabolite were measured. Thus, long-term exposure to $\mathrm{Al}$ increased the LPO levels in the parotid glands $\left(\mathrm{AlCl}_{3}: 140.4 \pm 9.01 \%\right.$; control: $100 \pm 5.61 \%$, $p=0.0018)$ and in the submandibular glands $\left(\mathrm{AlCl}_{3}: 194.1 \pm 23.9 \%\right.$; control: $100 \pm 15.89 \%$, $p=0.0187$ ) (Figure 1B).

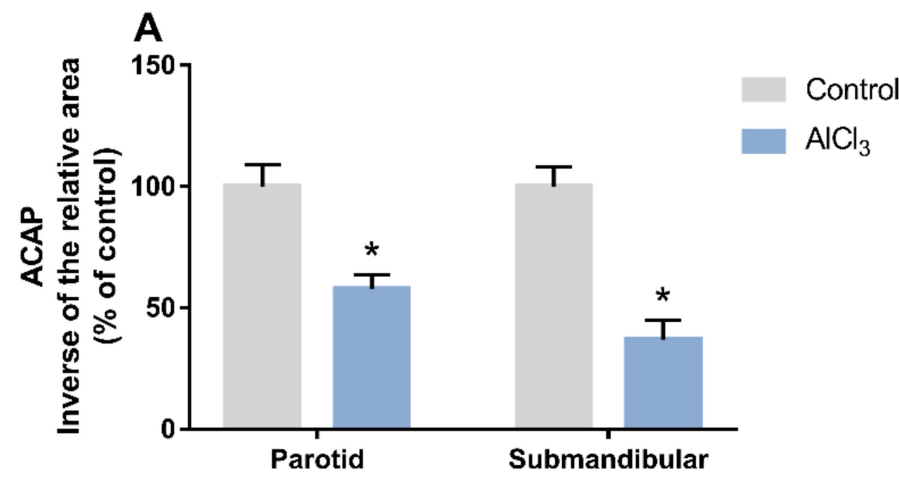

Figure 1. Cont. 


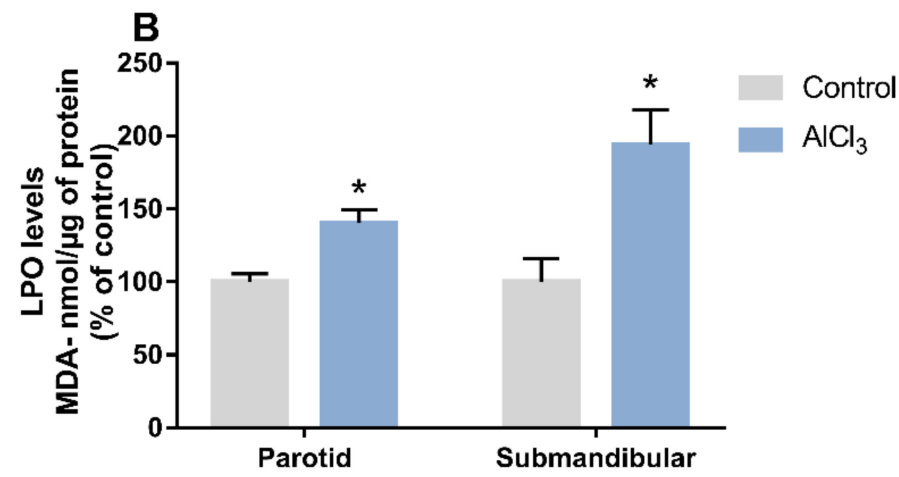

Figure 1. Effects of exposure to Aluminum Chloride $\left(\mathrm{AlCl}_{3}\right)(8.3 \mathrm{mg} / \mathrm{kg} /$ day $)$ for 60 days on the oxidative biochemistry of salivary glands. (A) Antioxidant capacity against peroxyl radicals (ACAP). (B) Lipid peroxidation (LPO) levels. The results are expressed as the mean \pm standard error of the mean (SEM). Student's $t$-test, ${ }^{*} p<0.05$.

\subsection{Long-Term $\mathrm{AlCl}_{3}$ Exposure Promoted Significant Changes in the Global Proteomic Profile of Major Salivary Glands}

A total of 372 proteins showed different regulation statuses in the parotid glands of rats. Among these proteins, 22 proteins were uniquely identified in the control group and 220 in the exposed group. In addition, the expression of 39 proteins was downregulated, and the expression of 91 was upregulated.

Regarding the submandibular proteome, a total of 63 proteins with different regulation statuses were identified. Among these, 49 proteins were uniquely identified in the control group and one protein was uniquely identified in the aluminum group. In a quantitative analysis between the groups, the expression of nine proteins was downregulated and the expression of four proteins was upregulated. The complete data are available in Tables S1 and S2.

According to Gene Ontology, the modulated proteins are related to 19 biological processes in the parotid glands. The top five most affected processes were proton transmembrane transport $(10 \%)$, followed by the regulation of axonogenesis $(8 \%)$, the glycolytic process $(8 \%)$, the establishment of protein localization to mitochondria $(6 \%)$, and antioxidant activity (6\%) (Figure 2A).

In the submandibular glands, 10 categories of biological processes were affected by aluminum exposure, of which the top five were structural constituents of the cytoskeleton $(20 \%)$, followed by fatty acid beta-oxidation $(14 \%)$, the glycolytic process $(11 \%)$, the cofactors of the catabolic process (11\%), and glial cell proliferation (8\%) (Figure 2B).

Based on the proteomic profile analysis, the data were compiled to evaluate the protein-protein interaction (PPI), the unique and different expression of the experimental groups in each salivary gland and the related biological functions with the Circos plot tool, an over-representation analysis (ORA). Thus, it was possible to observe the interactions of 60 proteins present in both glands considering their up/downregulation or absence between the control vs. aluminum group and the main biological processes involved (Figure 3). 


\section{A}

\section{Biological processes (\%)}

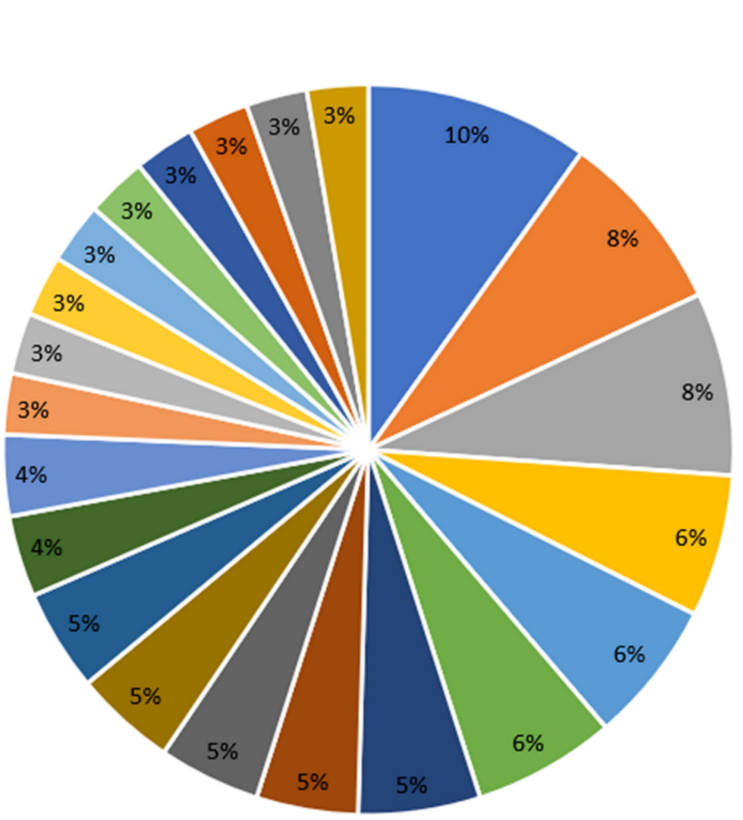

- Proton transmembrane transport

- Regulation of axonogenesis

- Glycolytic process

- Establishment of protein localization to mitochondrion

- Antioxidant activity

- Positive regulation of transporter activity

- Aerobic respiration

- Cellular response to cAMP

- Negative regulation of reactive oxygen species metabolic process

- Sodium:potassium-exchanging ATPase activity

- Sodium transmembrane transporter activity, phosphorylative mechanism

- Mesenchyme migration

" Nucleosome positioning

- Cellular response to interleukin-7

- Postsynaptic actin cytoskeleton organization

- Translational elongation

- Cortical actin cytoskeleton organization

- GDP-dissociation inhibitor activity

- Response to ATP

- Cellular response to epidermal growth factor stimulus

- Postsynaptic density organization

" Peptidyl-proline modification

\section{B}

\section{Biological processes (\%)}

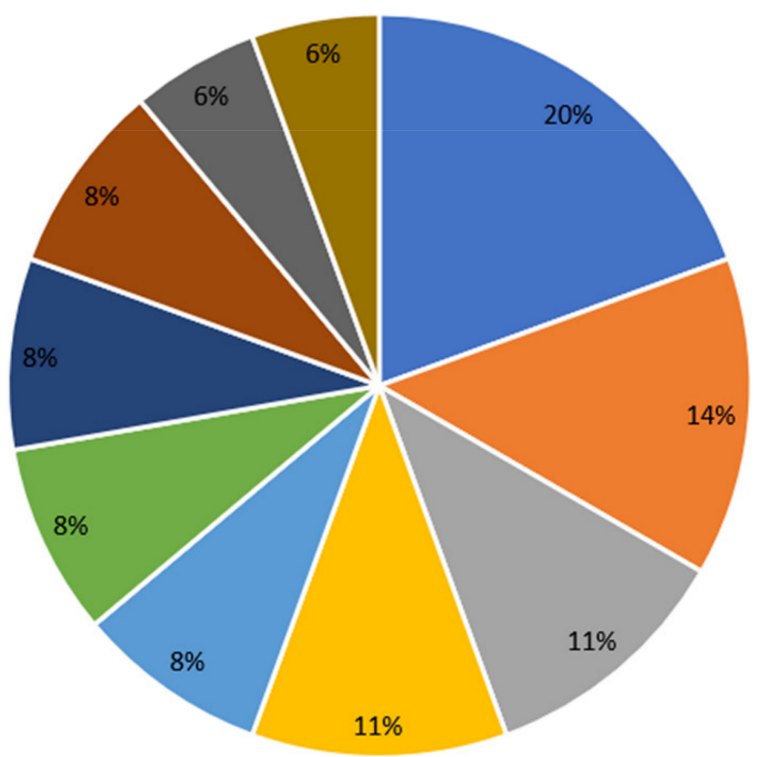

- Structural constituent of cytoskeleton

= Fatty acid beta-oxidation

= Glycolytic process

- Cofactor catabolic process

= Glial cell proliferation

= GDP-dissociation inhibitor activity

- Tricarboxylic acid cycle

- Protein refolding

- NAD metabolic process

- Structural constituent of postsynaptic actin cytoskeleton

Figure 2. Functional distribution of proteins identified with different expression (A) in the parotid glands and (B) in the submandibular glands of rats exposed to $\mathrm{AlCl}_{3}$ vs. control. Categories of proteins are based on Gene Ontology annotation of the biological process. Protein accession numbers were provided by Uniprot.org, accessed on 11 November 2021. The gene ontology was evaluated according to the ClueGo plugin of Cytoscapes software 3.6. 


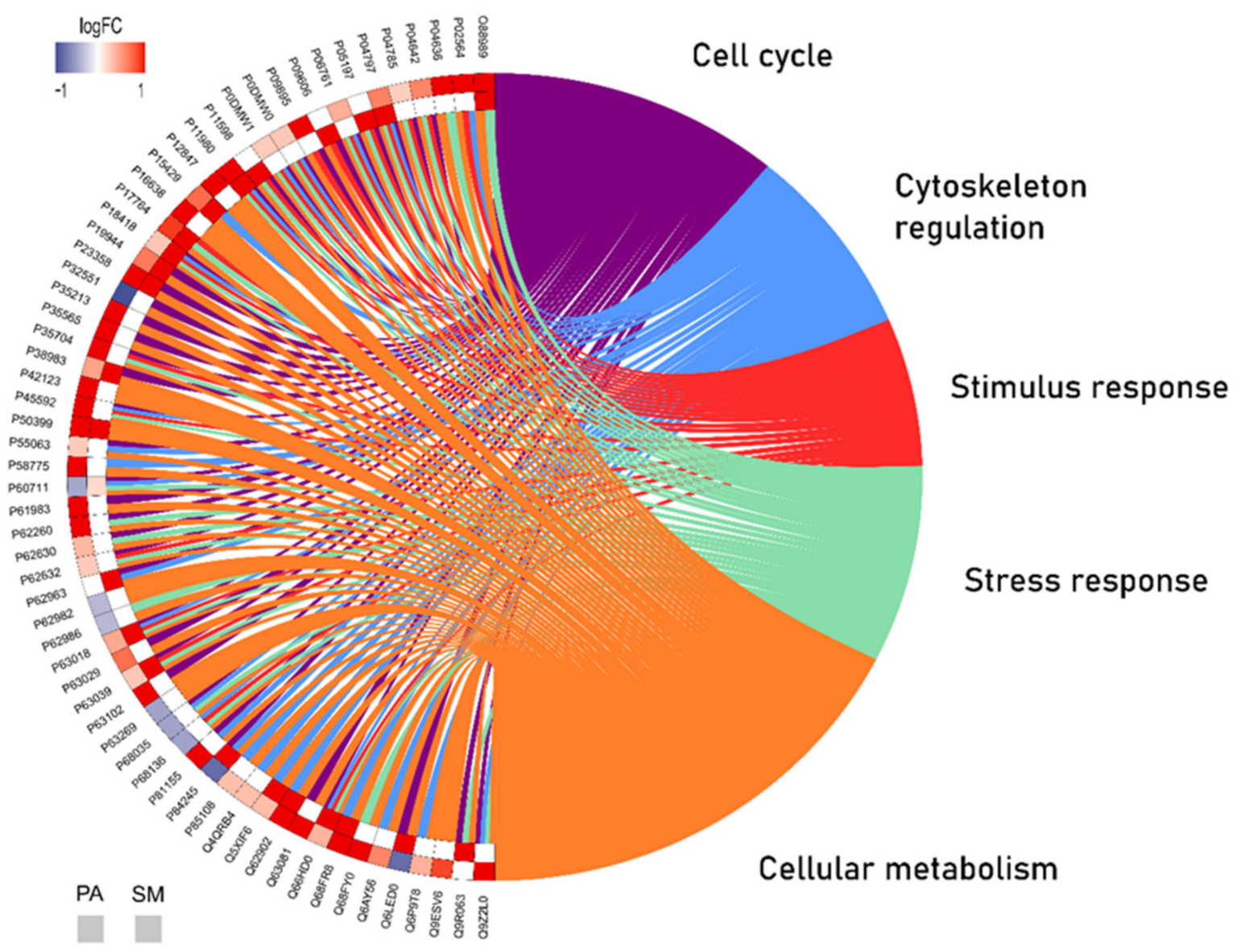

Figure 3. Over-representation analysis (Circos plot) presenting the protein-protein interactions between the aluminum and control groups in both parotid (PA; the outside square) and submandibular (SM; the inner square) glands and the biological processes involved according to Gene Ontology. The altered regulation is expressed according to the colors. Blue represents subexpression, red represents superexpression and white represents absence.

\subsection{Salivary Gland Morphology Was Affected by Chronic $\mathrm{AlCl}_{3}$ Exposure}

Histopathological analysis of the parotid glands revealed multiple serous acinus arranged in lobules, while in submandibular glands, the serous acinus was associated with mucous tubulous. Some major morphological differences were observed when comparing parotid and submandibular glands in both the control and $\mathrm{AlCl}_{3}$ groups. In the parotid glands, it was observed that the $\mathrm{AlCl}_{3}$ group exhibited smaller size of the acinus and a greater amount of stroma than the control group. In the submandibular glands, the $\mathrm{AlCl}_{3}$ group exhibited more stromal components and larger ductal structures than the control group. In addition, the size of the acinus from the $\mathrm{AlCl}_{3}$ group also appeared smaller than that of the control group. No inflammatory components were present in the analyzed glands.

After the morphometric measurements, it was found that in the parotid glands, the tissue of the parenchyma decreased $(p=0.0397)$, while the stromal tissue increased $(p=0.0011)$. The total acinar area also decreased after 60 days of exposure to $\mathrm{Al}(p=0.0326)$, but there were no significant changes in the total area of the ducts $(p=0.7852)$. A decrease in the submandibular gland's parenchyma area $(p=0.0001)$ was also observed, while the stromal tissue increased in the exposed group $(p<0.0001)$. In addition, the total acinar area decreased in the $\mathrm{AlCl}_{3}$ group compared to the control group $(p=0.0006)$. An increase in the total area of the ducts was observed in the $\mathrm{AlCl}_{3}$ group $(p=0.0312)$ (Table 1, Figure 4). 
Table 1. Morphometric measurements of the rats' salivary glands after long-term exposure to aluminum, $n=8$ /group (mean \pm SEM).

\begin{tabular}{|c|c|c|c|c|c|c|}
\hline \multirow{2}{*}{ Measures } & \multicolumn{3}{|c|}{ Parotid Glands } & \multicolumn{3}{|c|}{ Submandibular Glands } \\
\hline & Control Group & Aluminum Group & $p$ Value * & Control Group & Aluminum Group & $p$ Value * \\
\hline $\begin{array}{l}\text { Total parenchyma } \\
\text { area }\left(\mu \mathrm{m}^{2}\right)\end{array}$ & $64,563 \pm 2613$ & $58,262 \pm 1100$ & 0.0397 & $69,726 \pm 1713$ & $54,543 \pm 1564$ & 0.0001 \\
\hline $\begin{array}{l}\text { Total stroma } \\
\text { area }\left(\mu \mathrm{m}^{2}\right)\end{array}$ & $21,980 \pm 634$ & $28,803 \pm 734.7$ & 0.0011 & $4941 \pm 1099$ & $24,263 \pm 1473$ & $<0.0001$ \\
\hline $\begin{array}{l}\text { Total acinar } \\
\text { area }\left(\mu \mathrm{m}^{2}\right)\end{array}$ & $62,676 \pm 3062$ & $55,020 \pm 426.7$ & 0.0326 & $66,660 \pm 2079$ & $50,606 \pm 1911$ & 0.0006 \\
\hline $\begin{array}{l}\text { Total ductal } \\
\text { area }\left(\mu \mathrm{m}^{2}\right)\end{array}$ & $2325 \pm 611.8$ & $2159 \pm 279.7$ & 0.7852 & $3002 \pm 285.9$ & $4022 \pm 255.2$ & 0.0312 \\
\hline
\end{tabular}

*(Student's $t$ test, $p<0.05)$.
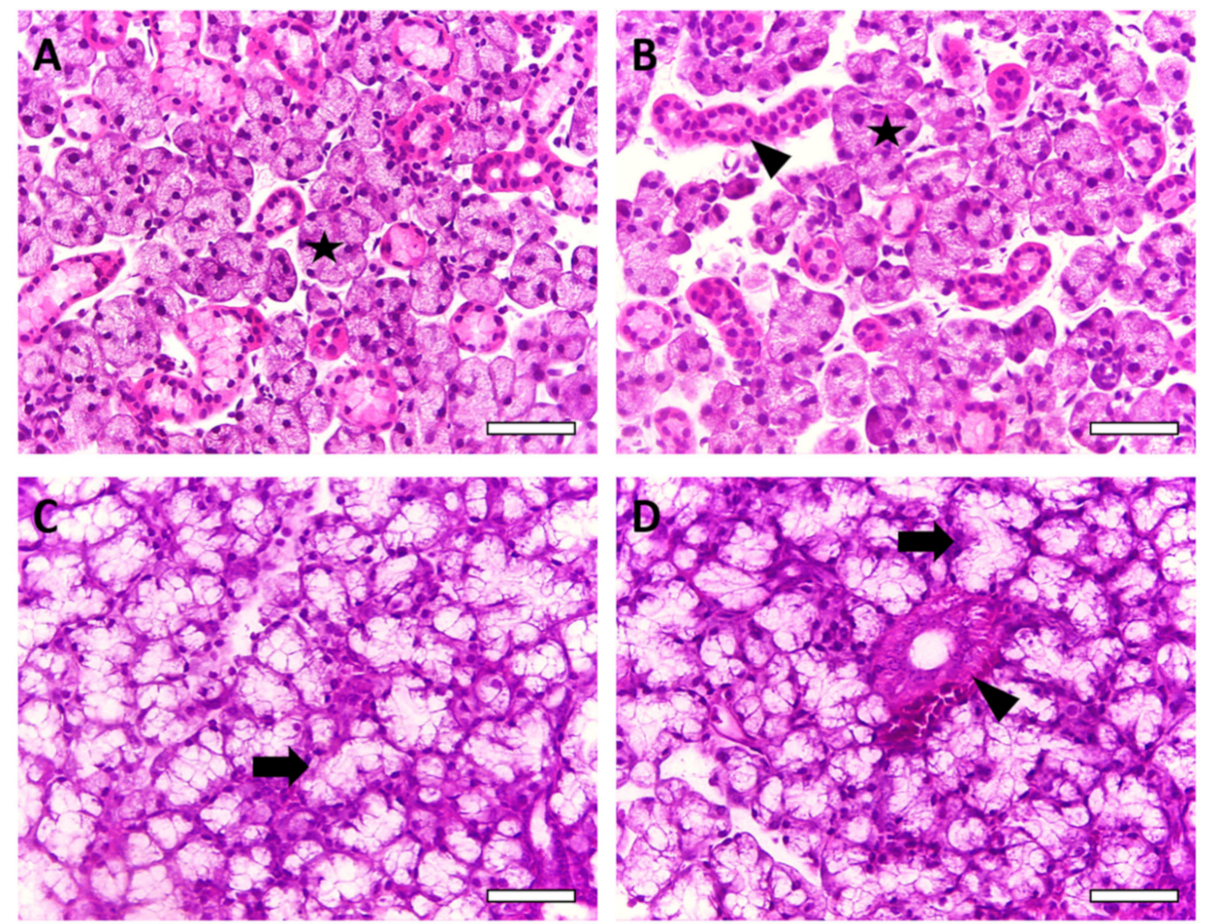

Figure 4. Effects of long-term $\mathrm{AlCl}_{3}$ exposure $(8.3 \mathrm{mg} / \mathrm{kg} /$ day) on rat salivary glands. Representative photomicrographs of (A) control and (B) aluminum parotid glands and (C) control and (D) aluminum submandibular glands. Stars indicate serous acinus; arrows indicate mucous tubulous and arrowheads indicate ducts. The sections were stained with hematoxylin and eosin (H\&E). Scale bar $=50 \mu \mathrm{m}$.

\section{Discussion}

Our study provides new evidence about the effects of $\mathrm{AlCl}_{3}$ on the major salivary glands of rats after long-term exposure at a dose equivalent to those which humans are exposed via dietary levels. In a previous study, $\mathrm{Al}$ was found to have harmful effects on the oxidative state and the morphology of salivary glands [22]. For a better understanding about the molecular state and how $\mathrm{Al}$ interacts in those organs, our study presents an unprecedented global proteomic investigation showing that long-term exposure to $\mathrm{Al}$ affects several biological processes in the salivary glands, such as energy metabolism, the cytoskeleton, and cell proliferation, and it is associated with oxidative biochemistry imbalance, which was found to culminate in a severe morphological impairment in both glands. 
Our study used a low dose that was described in a previous study as being able to promote changes in the central nervous system [10] and inperipheral organs [23] of rats. This dose was established considering the provisional acceptable weekly intake of $\mathrm{Al}$ by humans, which ranges from 1 to $2 \mathrm{mg} / \mathrm{kg}$ body weight in accordance to the joint FAO/World Health Organization Expert Committee on Food Additives [24], and an allometric calculation that considers the biological differences between rodents and humans, such as the body surface area of the species, which influences blood volume, caloric expenditure, and renal functions $[23,25]$.

To ensure $\mathrm{Al}$ consumption, $\mathrm{AlCl}_{3}$ was administered by orogastric gavage. In previous studies, this method triggered harmful effects in the central nervous system [10] and in other oral structures such as alveolar bone [26], and the success of this method was validated by the quantification of the blood concentration of Al. In those cited studies, the animals exposed to $\mathrm{AlCl}_{3}$ exhibited higher levels of $\mathrm{Al}$ in the blood in comparison with the non-exposed animals, without significant alterations in weight and mortality between the groups.

Our group has performed several studies regarding the effects of metals on the salivary glands in animal models, showing that those elements are capable of trigger tissue and redox impairments that affect the animals' stomatognathic system [16-22]. Other studies have also revealed damage to those organs after $\mathrm{Al}$ exposure $[27,28]$, but to the best of our knowledge, this is the first study that used a proteomic approach to investigate the effects of exposure to a translational dose of Al over salivary glands.

The mechanisms underlying Al are still not fully understood. One study gave evidence suggesting that $\mathrm{Al}$ is involved in oxidative stress conditions and may exert significant prooxidant activity [29]. This was suggested because $\mathrm{Al}^{3+}$ was previously reported to bind to the superoxide anion radical $\left(\mathrm{O}_{2}{ }^{-} \bullet\right.$, superoxide) to form the $\mathrm{Al}$ superoxide semireduced radical ion $\left(\mathrm{AlO}_{2}{ }^{2+} \bullet, \mathrm{Al}\right.$-superoxide complex) [30]. Computational approaches showed that these Al-superoxide complexes reduce Fe(III) to Fe(II) in Fenton's reaction, releasing oxygen molecules and generating ROS [31]. Increased reactive oxygen species (ROS) production and decreased antioxidant activity are the main factors leading to the imbalance between the oxidant and antioxidant systems and, consequently, oxidative stress [32]. In our study, the antioxidant competence, ACAP, was significantly reduced in both parotid and submandibular glands after exposure to Al (Figure 1A). A decrease in ACAP was previously observed in the central nervous system of rats exposed to $\mathrm{Al}$ [33] and our data show that other organs, such as salivary glands, can also be susceptible to changes in the antioxidant system in accordance with the existing literature on Al toxicology.

LPO levels were increased in both glands after Al exposure (Figure 1B). ROS are highly reactive and attack various classes of molecules including proteins, DNA, and lipids such as polyunsaturated fatty acids [34]. When the polyunsaturated fatty acid chain is oxidized, MDA and other molecules, such as 4-hydroxy-2-nonenal and F2-isoprostanes, are formed from this reaction [35]. These molecules are widely accepted biomarkers of oxidative stress because of its genotoxicity or cytotoxicity. In a previous study by our group, the levels of LPO, as well as ACAP levels, on salivary glands of mice were affected by Al exposure and those changes were also related to morphometry impairments [22]. In another study, $\mathrm{AlCl}_{3}$ caused increased LPO levels in the liver and kidneys of adult rats and also reduced levels of other antioxidant molecules such as superoxide dismutase and catalase, thereby causing oxidative stress [36]. Our data emphasize that oxidative stress may be one of the toxic mechanisms of $\mathrm{Al}$.

Previous reports have shown that major salivary glands are susceptible to metalinduced toxicity in models of exposure to lead [21], inorganic mercury [16], and methylmercury [17-19]. The last model also induces several proteomic damages, in the parotid and submandibular glands, especially changes in proteins related to cytoskeleton and energy metabolism pathways [17]. The bioinformatic analysis of the present study showed biological processes related to mitochondrial activity in the parotid gland and protein refolding in the submandibular gland, and these findings are suggestive of not only en- 
ergy metabolism impairment but also oxidative stress pathway activation and proteome protection impairment.

The heat shock proteins (HSP) family performs important homeostasis functions, and alterations in the expression of these proteins may be related to protein impairments in the organ of interest. HSPs have chaperone activity and have already been suggested as therapeutic strategies for many diseases due to their protective functions [37]. In our study, we observed upregulation of the expression of 'Heat shock $70 \mathrm{kDa}$ protein 1A' (P0DMW0), 'Heat shock $70 \mathrm{kDa}$ protein 1B' (P0DMW1), 'Heat shock $70 \mathrm{kDa}$ protein 1-like' (P55063), and 'Heat shock cognate $71 \mathrm{kDa}$ protein' (P63018) in the parotid glands, in addition to upregulation of ' $60 \mathrm{kDa}$ heat shock protein, mitochondrial' (P63039) expression in both glands. HSP expression alteration was also observed in hippocampal neurodegeneration after metal exposure, specifically methylmercury [38]. This HSP upregulation after Al exposure may reflect a cellular response that attempts to restore the system following oxidative stress in the salivary glands.

In addition, mitochondria are responsible for the redox state and mitochondrial failure is directly involved in changes in energy metabolism and oxidative stress [39]. Studies have shown that $\mathrm{Al}$ has the potential to disrupt the antioxidant defense system in different regions in rat brain $[10,27,33]$. $\mathrm{AlCl}_{3}$-induced oxidative stress was shown to modulate cytochrome $\mathrm{c}$ in the rat hippocampus, and the release of subunits of this protein is associated with apoptosis caused by activation of the caspase cascade [27,40]. In our study, mitochondrial changes were observed in the parotid glands, as indicated by the upregulation of the expression of 'Cytochrome c oxidase subunit 4 isoform 1, mitochondrial' (P10888) and 'Cytochrome c oxidase subunit 5A, mitochondrial' (P11240). Cytochrome c was also shown to be altered in liver dysfunction and mitochondrial energy metabolism disorder in rats exposed to $\mathrm{AlCl}_{3}$ [41].

Moreover, calcium homeostasis is also important to mitochondria. Excessive influx of calcium $\left(\mathrm{Ca}^{2+}\right)$ into this organelle generates more ROS and impairs mitochondrial membrane potential [42]. In the salivary glands exposed to Al, the expression of several proteins related to calcium homeostasis was upregulated in the submandibular glands; these proteins included 'Superoxide dismutase [Cu-Zn]' (P07632), 'Voltage-dependent anion-selective channel protein 1' (Q9Z2L0), and 'Peroxiredoxin-2 (P35704)' in the parotid glands, and 'Peroxiredoxin-5, mitochondrial' (Q9R063) in the submandibular glands. The upregulation these molecules could be related to more calcium influx increasing ROS and oxidative stress.

Our ORA analysis revealed the connections between the proteins in a PPI network, showing the most relevant biological processes involved. This study provides a better understanding of possible proteins related to mechanisms affecting both glands. The expression of the tubulin protein family, represented by the 'Tubulin alpha-4A chain' (Q5XIF6) and the 'Tubulin alpha-3 chain' (Q68FR8), was upregulated in both the parotid and submandibular glands from the Al-exposed animals. This group of proteins is the major component of microtubules, which support cells in many processes, including cell movement and mitosis [43]. 'Tubulin beta-3 chain' (Q4QRB4) was reported as being a possible biomarker of many ageing cells such as melanocytes and keratinocytes [44] and the expression of this protein and that of other isoforms of the tubulin family was upregulated in the parotid glands exposed to Al. On the other hand, tubulin isoforms were expressed exclusively in the exposed group of submandibular glands, which may be associated with the most altered biological process, the structural constituent of the cytoskeleton (20\%), according to the Gene Ontology (Figure 2B).

Similar to the tubulin family, other proteins are involved in the cellular metabolism and cell cycle of the salivary glands and are also upregulated in both glands, as shown in Figure 3. Malate dehydrogenase plays a role in cellular metabolism as the enzyme that catalyzes the conversion of oxaloacetate and malate utilizing the NAD/NADH coenzyme [45]. In eukaryotic cells, at least two forms of this enzyme can be observed. One isoform is a major enzyme of the citric acid cycle that operates within mitochondria, and the other is 
found in the cytosol [46]. The expression of the cytoplasmic isoform (O88989) was upregulated in both salivary glands after $\mathrm{Al}$ exposure. In the parotid gland, greater changes were identified in the biological process of proton transmembrane transport (10\%) (Figure 1A), which is related to changes in the activity of $\mathrm{Na}, \mathrm{K}$-ATPase enzymes. In turn, these proteins (P54708, Q64541) were upregulated in the group exposed to Al. These findings confirm the hypothesis that $\mathrm{Al}$ can affect salivary glands by changing the expression of important proteins related to the biochemical mechanisms responsible for the maintenance of cells. All these proteins could possibly be biomarkers of $\mathrm{Al}$ toxicity in salivary glands.

Actin is the major constituent of the microfilament apparatus in all eukaryotic cells and plays a crucial role in the cytoskeleton, especially in cell motility and muscle contraction [47]. In our study, the group of proteins related to the structural constituent of the cytoskeleton was the biological process group that was most affected in the submandibular glands (Figure 2B). Myoepithelial cells are contractile cells that are associated with the secretory cells of salivary glands, and are rich in actin proteins [48]. Myoepithelial cell contraction helps to expel saliva to the duct system in the mouth where it participates in lubrication and the initiation of digestion [49]. In both salivary glands exposed to $\mathrm{Al}$, the expression of 'Actin, gamma-enteric smooth muscle' (P63269) and 'Actin, cytoplasmic 1' (P60711) was dysregulated. Histological studies have already shown a decrease in smooth muscle actin immunostaining in the salivary glands of animals after lead exposure [21] and chronic stress [50]. Alterations in the expression of these proteins could be indicative of an impairment of the nervous stimulus transmission of myoepithelial cells affecting the salivary glands after exposure to $\mathrm{Al}$, which may be one of the routes of the toxic action for this metal.

Changes in actin expression were also associated with collagen accumulation in liver fibrosis due to the activation of the Rho pathway [51]. In our study, the expression of the 'Rho GDP dissociation inhibitor' (P50399) was upregulated in both salivary glands, which may be related to the histological findings in the salivary glands after exposure to Al. In the histopathological analysis, a greater amount of stroma in the parotid glands and more stroma components in the submandibular glands were observed on the $\mathrm{Al}$ group. This suggests that metal exposure could promote a change in mesenchymal cells' metabolism. Another protein related to cell proliferation is '60S acidic ribosomal protein $\mathrm{P1}^{\prime}$ (P19944) and its expression was upregulated in the parotid and submandibular glands after exposure to Al. Elevated expression of this ribosomal protein is associated with cell proliferation and invasion in several pathologies [52]. These proteome alterations support the hypothesis that cells react by undergoing molecular changes and try to respond to the harmful effects on tissues caused by $\mathrm{Al}$ intoxication.

In addition, the histological quantitative parameters revealed that in both glands, exposure to $\mathrm{Al}$ could change the ratio of the parenchyma area to the stroma area in the gland tissue (Table 1, Figure 4), indicating the loss of the epithelial component with reparative conjunctive tissue formation. Impairments in epithelial-mesenchymal interactions are associated with the development of pathological processes, such as fibrosis, in salivary glands [53]. Moreover, in the morphometric analysis, the salivary gland structures, mainly the submandibular glands, were also affected by $\mathrm{Al}$ exposure. The acinar area was reduced in both salivary glands, while the ductal area was increased in the submandibular glands (Table 1). Those morphometry changes were already observed in the salivary glands of rats exposed to methylmercury [20]. Acini is the gland structure where saliva is produced, and alterations in its morphology may impair the production of this important fluid [54]. Increased ductal area may be a cellular response for overcoming possible damage through regeneration mechanisms developed by granular and intercalated ducts [55]. The different responses in duct morphology seen in the parotid and submandibular glands may be explained by the different physiological and histological effects observed in the glands as they are two independent organs [55].

The parotid glands are predominantly formed by serous acinar cells that secrete aqueous saliva, which is rich in water and ions. The submandibular glands are composed 
of mixed acini with mucous and serous components that produce saliva that is rich in mucin and glycoconjugates [56]. Their duct systems are also different. The intercalated ducts are longer in the parotid glands than in the submandibular glands. The ducts are the structures responsible for transporting and modifying water and electrolyte concentrations, so differences in the duct system structures between the glands also affect the final saliva production [55]. Those characteristics may be the reason why each gland can develop different responses to $\mathrm{Al}$ intoxication.

\section{Materials and Methods}

\subsection{Ethics Statement and Experimental Groups}

This study was conducted after approval by the Ethics Committee on Experimental Animals of Federal University of Pará (under license number 5923210617), following the Guide for the Care and Use of Laboratory Animals [57]. This study followed the Animal Research: Reporting of In Vivo Experiments (ARRIVE) guidelines [58]. The sample size was calculated based on a normal distribution of the variables tested. A power of $80 \%$ and a bilateral alpha level of $5 \%$ were assumed with mean and standard deviation data of a previous study [17]. Thirty-two male Wistar rats (Rattus norvegicus, 35 days old), weighing approximately $100 \mathrm{~g}$, were divided by simple randomization into two groups ( $n=16$ /group): the aluminum group and the control group. Then, the rats were allocated to collective plastic cages ( 4 animals each). During the experimental period, the animals had ad libitum access to water-balanced pelleted food (Presence, Neovia, Brazil), and the temperature-controlled $\left(25^{\circ} \mathrm{C}\right)$ room was maintained under standard $12 \mathrm{~h} \mathrm{light/dark}$ cycle (lights on at 7:00 am) conditions. The steps of the method are summarized in Figure 5.

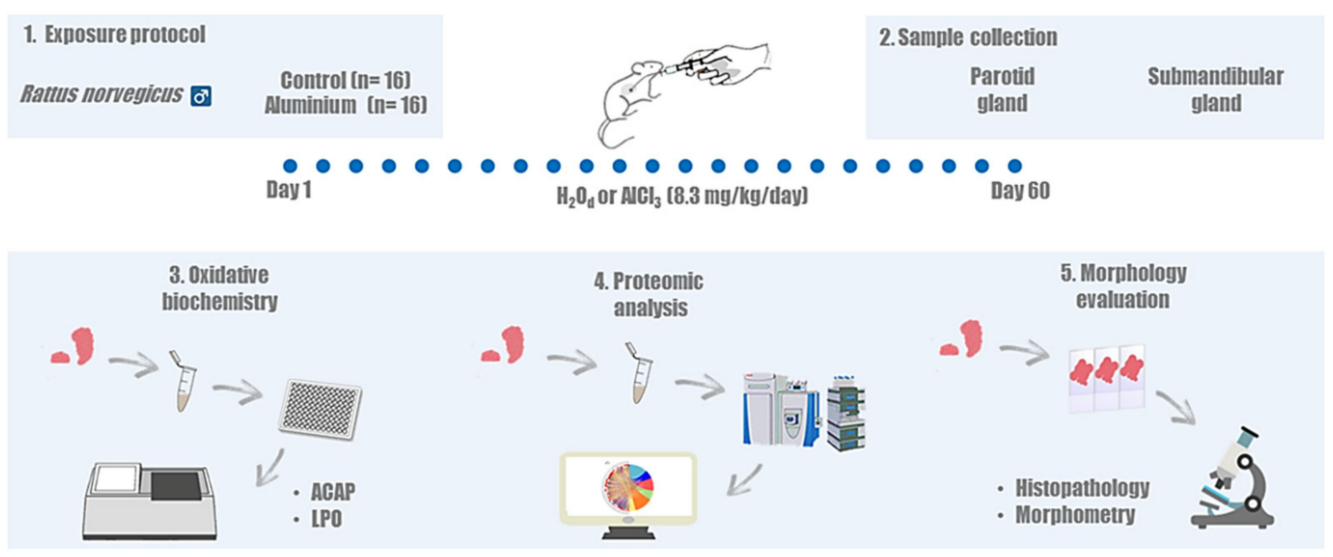

Figure 5. Methodological steps of the present study. (1) Description of experimental groups and exposure to aluminum chloride $\left(\mathrm{AlCl}_{3}\right)$ or distilled water $\left(\mathrm{H}_{2} \mathrm{Od}\right)$. (2) Collection of the biological samples. (3) Oxidative biochemistry assays performed by measuring the antioxidant capacity against peroxyl radicals (ACAP) and lipid peroxidation (LPO) levels. (4) Proteomic profile analysis performed by mass spectrometry system and (5) morphology analysis.

\subsection{Aluminum Exposure Protocol}

The aluminum group received $8.3 \mathrm{mg} / \mathrm{kg} /$ day of $\mathrm{AlCl}_{3}$ diluted in $8 \mathrm{mg} / \mathrm{mL}$ distilled water daily for 60 days. The exposure solution was administered by intragastric gavage. The dose of $\mathrm{AlCl}_{3}$ used in this study was described in previous studies as a low dose that is capable of promoting changes in biological systems, and corresponds to an animal dose translated from doses of Al to which humans are exposed via diet $[10,23]$. A previous study using the same experimental model measured the $\mathrm{Al}$ levels in animal blood and revealed that the treated animals showed higher $\mathrm{Al}$ levels $\left(\mathrm{AlCl}_{3}: 56.4 \pm 3.94 \mu \mathrm{gL}^{-1}\right.$; control: $\left.24.61 \pm 5.21 \mu \mathrm{gL}^{-1}, p<0.05\right)$ [10]. The control group received only distilled water $\left(\mathrm{H}_{2} \mathrm{Od}\right)$ following the same protocol. The animals were weighed weekly to correctly adjust the Al dose. 


\subsection{Sample Collection}

After the exposure period, the animals were anaesthetized with an intraperitoneal injection of $10 \%$ ketamine hydrochloride $(90 \mathrm{mg} / \mathrm{kg})$ and $2 \%$ xylazine hydrochloride $(9 \mathrm{mg} / \mathrm{kg})$. For eight randomly chosen animals per group, after complete loss of reflexes, the salivary glands were collected and then stored at $-80{ }^{\circ} \mathrm{C}$ for further biochemistry and proteomic assays. The remaining eight animals per group were perfused for histological analysis.

\subsection{Biochemical Assays}

Samples were thawed and resuspended in a Tris- $\mathrm{HCl}$ solution $(20 \mathrm{mM}, \mathrm{pH} 7.4)$ for sonic disintegration $(\sim 1 \mathrm{~g} / \mathrm{mL})$. Then, the total homogenate was used in both the ACAP assay and the LPO assay.

\subsubsection{Antioxidant Capacity against Peroxyl Radicals Assay}

ACAP was analyzed using the ROS quantitation produced by the equally-concentrated samples $(2.5 \mu \mathrm{g}$ proteins $/ \mu \mathrm{L})$ after exposure to a peroxyl radical generator [59]. Peroxyl radicals were produced by the thermal $\left(35^{\circ} \mathrm{C}\right)$ decomposition of 2,2'-azobis 2 methylpropionamidine dihydrochloride (ABAP; 4 mM; Sigma-Aldrich, St. Louis, MI, USA). For ROS determination, the compound $2^{\prime}, 7^{\prime}$-dichlorofluorescein diacetate $\left(\mathrm{H}_{2} \mathrm{DCF}-\mathrm{DA}\right.$, Invitrogen ${ }^{\mathrm{TM}}$, Whaltan, MA, USA) was used at a final concentration of $40 \mathrm{nM}$. The readings were carried out in a fluorescence microplate reader (Victor X3, Perkin Elmer, Waltham, MA, USA) every $5 \mathrm{~min}$ for $1 \mathrm{~h}$. The relative difference between ROS area with and without ABAP was considered as a measure of antioxidant capacity. From that, the results were transformed to the inverse of the relative area and expressed as \% of control.

\subsubsection{Lipid Peroxidation Assay}

LPO levels in the samples were measured using MDA levels as an indicator [60]. After sonic homogenization, lysates were centrifuged at $3512 \times g$ for $10 \mathrm{~min}$ at $4{ }^{\circ} \mathrm{C}$. Supernatants and standard solutions of MDA were then incubated with a 1:4 solution of methanesulfonic acid:N-methyl-2-phenylindole $10.3 \mathrm{mM}$ diluted in methanol (1:3), at $45^{\circ} \mathrm{C}$ for $40 \mathrm{~min}$, followed by spectrophotometric reading $(\lambda=570 \mathrm{~nm})$. The results are expressed in nanomol per microgram $(\mathrm{nmol} / \mu \mathrm{g})$ of protein and graphed as a percentage of the control. Protein quantification was performed using the Bradford method [61].

\subsection{Proteomic Analysis}

\subsubsection{Protein Extraction}

Proteomic analysis was performed according to previously described protocols [38,61]. The samples were cryofractured in liquid nitrogen using a cryogenic mill, and soluble proteins were extracted with lysis buffer (7 M urea, $2 \mathrm{M}$ thiourea, diluted in ammonium bicarbonate $(\mathrm{AmBic})$ ) under constant stirring at $4{ }^{\circ} \mathrm{C}$. The samples were centrifuged for $30 \mathrm{~min}$ at $14,000 \mathrm{rpm}$ at $4{ }^{\circ} \mathrm{C}$, and the total protein concentrations in the supernatants were quantified using Bradford's method [62]. The assay was carried out in biological triplicate and two samples from different animals were pooled into one. Subsequently, we collected $50 \mu \mathrm{g}$ of protein from each pooled sample and added AmBic (50 mM) until final concentrations of $1 \mu \mathrm{g} / \mu \mathrm{L}$ were reached. Quantities of $10 \mu \mathrm{L}$ of AmBic and $25 \mu \mathrm{L}$ of $0.2 \%$ RapiGEST ${ }^{\mathrm{TM}}$ (Waters Co., Manchester, UK) were added and incubated at $37^{\circ} \mathrm{C}$ for $30 \mathrm{~min}$, followed by the addition of $2.5 \mu \mathrm{L}$ of $100 \mathrm{mM}$ dithiothreitol and incubation at $37^{\circ} \mathrm{C}$ for $60 \mathrm{~min}$. Then, we added $2.5 \mu \mathrm{L}$ of iodoacetamide $(300 \mathrm{mM})$; BioRad, Hercules, CA, USA) before incubation for $30 \mathrm{~min}$ at room temperature in the dark. Subsequently, $10 \mu \mathrm{L}$ of trypsin (Thermo Fischer, Waltham, MA, USA) were added and the digestion occurred for $14 \mathrm{~h}$ at $37^{\circ} \mathrm{C}$. Furthermore, $10 \mu \mathrm{L}$ of $5 \%$ trifluoroacetic acid (Sigma-Aldrich, St. Louis, MI, USA) was added. The samples were incubated at $90 \mathrm{~min}$ at $37^{\circ} \mathrm{C}$, which was followed by posterior centrifugation at $14,000 \mathrm{rpm}$ at $6{ }^{\circ} \mathrm{C}$ for $30 \mathrm{~min}$. The supernatants were collected and purified using C18 spin columns (Pierce, Waltham, MA, USA). The samples were resuspended in $12 \mu \mathrm{L}$ of alcohol dehydrogenase $(1 \mathrm{pmol} / \mu \mathrm{L}), 108 \mu \mathrm{L}$ of $3 \%$ acetonitrile 
(Sigma-Aldrich, St. Louis, MI, USA), and 0.1\% formic acid (Thermo Fischer, Waltham, MA, USA).

\subsubsection{Mass Spectrometry Analysis}

The label-free proteomic analysis was performed in a nanoACQUITY UPLC system (Waters, Milford, MA, USA) coupled to a Xevo Q-TOF G2 mass spectrometer (Waters, Milford, MA, USA). The nanoACQUITY UPLC system was equipped with a Trap Columm $(100 \AA, 5 \mu \mathrm{m}, 180 \mu \mathrm{m} \times 200 \mathrm{~mm}$ ) and a HSS T3 M-Class type column (analytical column $75 \mu \mathrm{m} \times 150 \mathrm{~mm} ; 1.8 \mu \mathrm{m}$ ) (Waters, Milford, MA, USA). The reading and identification of peptides was performed using the ProteinLynx GlobalServer software (PLGS) version 3.03 (Waters, Milford, MA, USA), as previously described [63]. The PLGS software, applying the Monte-Carlo algorithm, was used to determine the difference in protein expression between the groups, considering $p<0.05$ for downregulated proteins and $1-p>0.95$ for upregulated proteins. The identification of proteins was performed by downloading UniProt databases. Then, bioinformatics analyses were performed using Cytoscape ${ }^{\circledR} 3.6$ $\left(\mathrm{Java}^{\circledR}\right.$ ) with the ClusterMarker plugin for the PPI network, and for the determination of the biological process groups based on Gene Ontology annotations, we used the ClueGO plugin [64].

\subsubsection{Over-Representation Analysis}

A table was generated containing the names of the proteins and their respective Log2Ratio values. For proteins with absolute changes, a value of -1 was adopted when the protein was present only in the control group and 1 was adopted when the protein was present in the exposed group.

For the ORA analysis, R studio software [65] was used with the EGSEA package [66]. In this step, the UNIPROT database was consulted to identify the proteins and the biological processes in which they participate; this database was made available by the Bader Lab. After this verification, we used Cytoscape software [67] with the Enrichment Map plugin to group the sets of proteins that were previously examined, after which the main biological processes were selected for graphic analysis.

Then, a PPI analysis (https://www.networkanalyst.ca/, accessed on 11 November 2021) [68] was performed to generate a representative image containing the top interacting proteins, which were categorized according to the number of protein interactions. The image was generated by R studio software with the GOplot plugin.

\subsection{Perfusion and Histological Analysis}

Eight animals from each group were deeply anaesthetized and then perfused with a saline $(\mathrm{NaCl} 0.9 \%)$ heparinized (1\%) solution, followed by a paraformaldehyde $4 \%$ buffered solution $(0.2 \mathrm{M})$. The submandibular and parotid glands were removed for histological procedures. The salivary glands were postfixed in $4 \%$ formaldehyde until processing. Then, the glands were dehydrated by incubation in solutions with increasing concentrations of ethanol (70\%, 80\%, 90\%, absolute 1, absolute 2), diaphanized in xylol, and embedded in Paraplast (McCormick Scientific, Baltimore, Maryland, EUA). Using a microtome, sections of $5 \mu \mathrm{m}$ thickness were obtained. These sections were stained with hematoxylin and eosin.

For the histopathological analysis, the evaluation was performed by two oral pathologists, who were blinded to the treatments, using an optical microscope (Axiophot ZEISS, Hallbergmoos, Germany). This evaluation of the salivary glands was described in a previous study [20], and the following two criteria were used: (1) the relationship between parenchyma (ducts and acini) and stroma (collagen fibers, inflammatory infiltrate, and blood vessels), which describes possible changes in the parenchyma $\times$ stroma relationship and (2) possible cellular changes in the glandular parenchyma, defined as atrophy, vacuolization, and/or degranulation.

For the morphometric analysis, images were taken by a colored digital camera coupled to an optic microscope (Leica Microscope DM750, Leica Microsystems ${ }^{\circledR}$, Switzerland, 40× 
magnification); images of 5 random sagittal sections of the glands, including 5 fields of view of each section, were captured. The total parenchyma area, total stroma area, total acinar area, and total duct area parameters of tissue morphology were evaluated and expressed in $\mu \mathrm{m}^{2}$ [69]. The values were obtained using the ImageJ software (NIMH, NIH, Bethesda, MD, USA) digital image analyzer.

\subsection{Statistical Analysis}

The data obtained in this study were plotted using GraphPad Prism 7.0 software (San Diego, CA, USA). The values obtained from the oxidative biochemical assays and histological analysis were evaluated for normality with the Shapiro-Wilk method and then compared using the Student's $t$-test. The significance level was $p<0.05$. The results are expressed as the mean \pm standard error of the mean (SEM). The test power was calculated based the differences between the group averages with OpenEpi software (Version 2.3.1), considering a type-I error of $5 \%$ and a power of $80 \%$ (for all values, see Table S3). In the proteomic analysis, the PLGS software was used to obtain the differences in protein expression between the groups, applying the Monte-Carlo algorithm $(p<0.05$ for downregulated proteins and $1-p>0.95$ for upregulated proteins).

\section{Conclusions}

For the first time, changes in the proteome profile of parotid and submandibular glands after low- and long-term Al exposure were demonstrated. These changes were associated with glandular oxidative stress and morphological impairments. We showed different responses by the glands due to their different characteristics, but all the results led to the suggestion that Al exert harmful effects on these organs. More studies are needed to better understand the toxic effect of $\mathrm{Al}$ on salivary glands and the potential functional failure outcomes.

Supplementary Materials: The following supporting information can be downloaded at: https: / / www.mdpi.com/article/10.3390/ijms23042251/s1.

Author Contributions: Conceptualization, D.S.-M. and R.R.L.; methodology, D.S.-M., M.C.d.S.G., L.O.B., W.A.B.A. and R.R.L.; formal analysis, A.D., M.A.R.B., M.D.M., M.E.C.-L. and R.R.L.; investigation, D.S.-M., L.O.B., W.A.B.A. and F.M.S.; resources, M.A.R.B., M.D.M., M.E.C.-L. and R.R.L.; data curation, R.R.L.; writing-original draft preparation, D.S.-M., L.O.B., W.A.B.A. and F.M.S.; writing-review and editing, A.D., M.E.C.-L. and R.R.L.; supervision, R.R.L.; project administration, R.R.L.; funding acquisition, R.R.L. All authors have read and agreed to the published version of the manuscript.

Funding: This work was supported by the Research Pro-Rectory of the Federal University of Pará (PROPESP, UFPA, Brazil), which paid the APC, Brazilian National Council for Scientific and Technological Development (CNPq), Programa Nacional de Cooperação Acadêmica na Amazônia-PROCAD/ Amazônia da Coordenação de Aperfeiçoamento de Pessoal de Nível Superior (CAPES). This study was financed in part by Coordination for the Improvement of Higher Education Personnel, Brazil (CAPES), Finance Code 001.

Institutional Review Board Statement: The animal study protocol was approved by the Ethics Committee on Experimental Animals of the Federal University of Pará (under protocol number 5923210617; 21 September 2017).

Informed Consent Statement: Not applicable.

Data Availability Statement: All data are available within the article and in Supplementary Materials.

Conflicts of Interest: The authors declare no conflict of interest. 


\section{References}

1. Carson, B.L. Aluminum compounds. Review of toxicological literature. In Abridged Final Report, Integrated Laboratory Systems; Research Triangle Park: North Carolina, NC, USA, 2000; p. 84.

2. Associação Brasileira do Alumínio (ABAL). Fundamentos e Aplicações do Alumínio; Associação Brasileira do Alumínio: São Paulo, Brazil, 2007.

3. Monteiro, M.A. Meio século de mineração industrial na Amazônia e suas implicações para o desenvolvimento regional. Estud. Avançados 2008, 19, 187-207. [CrossRef]

4. De Meyer, C.M.C.; Rodríguez, J.M.; Carpio, E.A.; García, P.A.; Stengel, C.; Berg, M. Arsenic, manganese and aluminum contamination in groundwater resources of Western Amazonia (Peru). Sci. Total Environ. 2017, 607-608, 1437-1450. [CrossRef] [PubMed]

5. European Food Safety Authority (ESFA). Dietary exposure to aluminium-containing food additives. EFSA Supporting Publ. 2013, $10,411 \mathrm{E}$.

6. Lin, Y.-J.; Shih, Y.-J.; Chen, C.-H.; Fang, C.-T. Aluminum salts as an adjuvant for pre-pandemic influenza vaccines: A meta-analysis. Sci. Rep. 2018, 8, 1-7. [CrossRef]

7. Yokel, R.A.; Florence, R.L. Aluminum bioavailability from tea infusion. Food Chem. Toxicol. 2008, 46, 3659-3663. [CrossRef]

8. Poole, R.L.; Hintz, S.R.; Mackenzie, N.I.; Kerner, J.A., Jr. Aluminum exposure from pediatric parenteral nutrition: Meeting the new FDA regulation. J. Parenter. Enteral Nutr. 2008, 32, 242-246. [CrossRef] [PubMed]

9. Yokel, R.A.; Mcnamara, P. Aluminium toxicokinetics: An updated minireview. J. Pharmacol. Toxicol. 2001, 88, 159-167. [CrossRef]

10. Fernandes, R.M.; Nascimento, P.C.; Martins, M.K.; Bragança Aragão, W.A.; Rivera, L.F.; Bittencourt, L.O.; Cartágenes, S.C.; Crespo-Lopez, M.E.; Maia, C.; Lima, R. Evaluation of Cerebellar Function and Integrity of Adult Rats After Long-Term Exposure to Aluminum at Equivalent Urban Region Consumption Concentrations. Biol. Trace Elem. Res. 2020, 199, 1-12. [CrossRef]

11. Yu, L.; Zhai, Q.; Yin, R.; Li, P.; Tian, F.; Liu, X.; Zhao, J.; Gong, J.; Zhang, H.; Chen, W. Lactobacillus plantarum CCFM639 Alleviate Trace Element Imbalance-Related Oxidative Stress in Liver and Kidney of Chronic Aluminum Exposure Mice. Biol. Trace Elem. Res. 2017, 176, 342-349. [CrossRef] [PubMed]

12. Costa, N.M.M.; Correa, R.S.; Júnior, I.S.M.; Figueiredo, A.J.R.; Vilhena, K.F.B.; Farias-Junior, P.M.A.; Teixeira, F.B.; Ferreira, N.M.M.; Pereira-Júnior, J.B.; Dantas, K.D.G.F. Physical, Chemical, and Immunohistochemical Investigation of the Damage to Salivary Glands in a Model of Intoxication with Aluminium Citrate. Int. J. Environ. Res. 2014, 11, 12429-12440. [CrossRef] [PubMed]

13. Miletich, I. Introduction to salivary glands: Structure, function and embryonic development. Front. Oral Biol. 2010, 14, 1-20.

14. Plemons, J.M.; Al-Hashimi, I.; Marek, C.L. American Dental Association Council on Scientific Affairs. Managing xerostomia and salivary gland hypofunction: Executive summary of a report from the American Dental Association Council on Scientific Affairs. J. Am. Dent. Assoc. 2014, 145, 867-873. [CrossRef]

15. Walsh, L.J. Dry mouth: A clinical problem for children and young adults. Int. Dent. SA 2010, 9, 48-58.

16. Aragão, W.A.B.; Costa, M.; Fagundes, N.; Silva, M.; Alves, S.; Pinheiro, J.; Amado, L.; Crespo, M.; Maia, C.; Lima, R. Chronic exposure to inorganic mercury induces biochemical and morphological changes in the salivary glands of rats. Metallomics 2017, 9, 1271-1278. [CrossRef]

17. Bittencourt, L.O.; Dionizio, A.; Nascimento, P.C.; Puty, B.; Leao, L.K.R.; Luz, D.A.; Silva, M.C.F.; Amado, L.L.; Leite, A.; Buzalaf, M.R. Proteomic approach underlying the hippocampal neurodegeneration caused by low doses of methylmercury after long-term exposure in adult rats. Metallomics 2019, 11, 390-403. [CrossRef]

18. Farias-Junior, P.M.A.; Teixeira, F.B.; Fagundes, N.C.; Miranda, G.F.; Bittencourt, L.O.; de Oliveira, R.O.; Silva, M.C.; Sagica, S.; de Oliveira, E.; Crespo-López, M.E.; et al. Chronic intoxication by methylmercury leads to oxidative damage and cell death in salivary glands of rats. Metallomics 2017, 9, 1778-1785. [CrossRef] [PubMed]

19. Lima, L.A.; Bittencourt, L.; Puty, B.; Fernandes, R.; Nascimento, P.; Silva, M.C.; Alves-Junior, S.; Pinheiro, J.; Lima, R. Methylmercury intoxication promotes metallothionein response and cell damage in salivary glands of rats. Biol. Trace Elem. Res. 2018, 185, 135-142. [CrossRef]

20. Nascimento, P.C.; Ferreira, M.K.; Balbinot, K.M.; Alves-Junior, S.M.; Pinheiro, J.V.; Silveira, F.M.; Martins, M.D.; Lopez, E.M.; Lima, R.R. Methylmercury-Induced Toxicopathologic Findings in Salivary Glands of Offspring Rats After Gestational and Lactational Exposure. Biol. Trace Elem. Res. 2020, 199, 1-9. [CrossRef]

21. Oliveira, L.G.; Aragão, W.; Nascimento, P.; Bittencourt, L.; Oliveira, A.; Leão, L.; Alves-Júnior, S.; Pinheiro, J.; Crespo-Lopez, M.; Lima, L. Effects of lead exposure on salivary glands of rats: Insights into the oxidative biochemistry and glandular morphology. Environ. Sci. Pollut. Res. 2020, 28, 1-13.

22. Souza-Monteiro, D.; Nunes, P.B.O.; Ferreira, R.O.; Eiró, L.G.; Bittencourt, L.O.; Chemelo, V.S.; Santos, S.M.; Souza-Rodrigues, R.D.; Monteiro, M.C.; Lima, R.R. Aluminum-Induced Toxicity in Salivary Glands of Mice After Long-term Exposure: Insights into the Redox State and Morphological Analyses. Biol. Trace Elem. Res. 2020, 198, 575-582. [CrossRef]

23. Martinez, C.S.; Escobar, A.G.; Uranga-Ocio, J.A.; Pecanha, F.M.; Vassallo, D.V.; Exley, C.; Miguel, M.; Wiggers, G.A. Aluminum exposure for 60 days at human dietary levels impairs spermatogenesis and sperm quality in rats. Reprod. Toxicol. 2017, 73, 128-141. [CrossRef] [PubMed]

24. Joint FAO/WHO Expert Committee on Food Additives (WHO). Meeting, \& World Health Organization. Evaluation of Certain Food Additives and Contaminants: Seventy-Third Report of the Joint FAO/WHO Expert Committee on Food Additives; World Health Organization: Geneva, Switzerland, 2011; p. 73. 
25. Reagan-Shaw, S.; Nihal, M.; Ahmad, N. Dose translation from animal to human studies revisited. FASEB J. Off. Publ. Fed. Am. Soc. Exp. Biol. 2008, 22, 659-661. [CrossRef] [PubMed]

26. Souza-Monteiro, D.; Ferreira, R.O.; Eiró, L.G. Long-term exposure to low doses of aluminum affects mineral content and microarchitecture of rats alveolar bone. Environ. Sci. Pollut. Res. 2021, 28, 45879-45890. [CrossRef] [PubMed]

27. Cao, Z.; Wang, P.; Gao, X.; Shao, B.; Zhao, S.; Li, Y. Lycopene attenuates aluminum-induced hippocampal lesions by inhibiting oxidative stress-mediated inflammation and apoptosis in the rat. J. Inorg. Biochem. 2019, 193, 143-151. [CrossRef] [PubMed]

28. Denisov, A.B. Morphological and functional state of major salivary glands under conditions of aluminum chloride excess in drinking water. Bull. Exp. Biol. Med. 2009, 148, 940-942. [CrossRef] [PubMed]

29. Exley, C. What is the risk of aluminium as a neurotoxin? Expert Rev. Neurother. 2014, 14, 589-591. [CrossRef]

30. Ruipérez, F.; Mujika, J.; Ugalde, M.; Exley, C.; Lopez, X. Pro-oxidant activity of aluminum: Promoting the Fenton reaction by reducing Fe (III) to Fe (II). J. Inorg. Biochem. 2012, 117, 118-123. [CrossRef]

31. Mujika, J.I.; Rezabal, E.; Mercero, J.; Ruipérez, F.; Costa, D.; Ugalde, J.; Lopez, X. Aluminium in biological environments: A computational approach. Comput. Struct. Biotechnol. J. 2014, 9, e201403002. [CrossRef]

32. Samarghandian, S.; Azimi-Nezhad, M.; Farkhondeh, T.; Samini, F. Anti-oxidative effects of curcumin on immobilization-induced oxidative stress in rat brain, liver and kidney. Biomed. Pharmacother. 2017, 87, 223-229. [CrossRef]

33. Fernandes, R.M.; Corrêa, M.; Aragão, W.; Nascimento, C.; Cartágenes, S.; Rodrigues, C.; Sarmiento, L.; Monteiro, M.; Maia, C.; Crespo-López, M.; et al. Preclinical evidences of aluminum-induced neurotoxicity in hippocampus and pre-frontal cortex of rats exposed to low doses. Ecotoxicol. Environ. Saf. 2020, 206, 111139. [CrossRef]

34. Furnkranz, A.; Leitinger, N. Regulation of inflammatory responses by oxidized phospholipids: Structure-function relationships. Curr. Pharm. Des. 2004, 10, 915-921. [CrossRef]

35. Tsikas, D. Assessment of lipid peroxidation by measuring malondialdehyde (MDA) and relatives in biological samples: Analytical and biological challenges. Anal. Biochem. 2017, 524, 13-30. [CrossRef]

36. Othman, M.S.; Fareid, M.A.; Abdel Hameed, R.S.; Abdel Moneim, A.E. The Protective Effects of Melatonin on Aluminum-Induced Hepatotoxicity and Nephrotoxicity in Rats. Oxid. Med. Cell. Longev. 2020, 2020, 7375136. [CrossRef] [PubMed]

37. Almeida, M.B.; do Nascimento, J.L.M.; Herculano, A.M.; Crespo-López, M.E. Molecular chaperones: Toward new therapeutic tools. Biomed. Pharmacother. 2011, 65, 239-243. [CrossRef]

38. Bittencourt, L.O.; Puty, B. Oxidative biochemistry disbalance and changes on proteomic profile in salivary glands of rats induced by chronic exposure to methylmercury. Oxid. Med. Cell. Longev. 2017, 2017, 5653291. [CrossRef] [PubMed]

39. Araujo, T.T.; Pereira, H. Changes in energy metabolism induced by fluoride: Insights from inside the mitochondria. Chemosphere 2019, 236, 124357. [CrossRef]

40. Mazumder, S.; Pleasca, D. Caspase-3 activation is a critical determinant of genotoxic stress-induced apoptosis. Apoptosis Cancer Hum. Press. 2008, 414, 13-21.

41. Xu, F.; Liu, Y.; Zhao, H.; Yu, K.; Song, M.; Zhu, Y.; Li, Y. Aluminum chloride caused liver dysfunction and mitochondrial energy metabolism disorder in rat. J. Inorg. Biochem. 2017, 174, 55-62. [CrossRef] [PubMed]

42. Redpath, C.J.; Bou Khalil, M.; Drozdzal, G.; Radisic, M.; McBride, H.M. Mitochondrial hyperfusion during oxidative stress is coupled to a dysregulation in calcium handling within a C2C12 cell model. PLoS ONE 2013, 8, e69165.

43. Binarová, P.; Tuszynski, J. Tubulin: Structure, Functions and Roles in Disease. Cells 2019, 8, 1294. [CrossRef]

44. Lehmann, S.G.; Bourgoin-Voillard, S.; Seve, M.; Rachidi, W. Tubulin Beta-3 Chain as a New Candidate Protein Biomarker of Human Skin Aging: A Preliminary Study. Oxid. Med. Cell. Longev. 2017, 2017, 5140360. [CrossRef] [PubMed]

45. Dasika, S.K.; Vinnakota, K.C.; Beard, D.A. Determination of the catalytic mechanism for mitochondrial malate dehydrogenase. Biophys. J. 2015, 108, 408-419. [CrossRef] [PubMed]

46. Minárik, P.; Tomásková, N.; Kollárová, M.; Antalík, M. Malate dehydrogenases-structure and function. Gen. Physiol. Biophys. 2002, 21, 257-265. [PubMed]

47. Witjes, L.; Van Troys, M.; Vandekerckhove, J.; Vandepoele, K.; Ampe, C. A new evolutionary model for the vertebrate actin family including two novel groups. Mol. Phylogenet. Evol. 2019, 141, 106632. [CrossRef] [PubMed]

48. Arnoldi, R.; Chaponnier, C.; Gabbiani, G.; Hinz, B. Heterogeneity of Smooth Muscle; Elsevier: Amsterdam, The Netherlands, 2012; pp. 1183-1195.

49. Hand, A.R. Salivary Glands, Anatomy and Histology; Elsevier: Amsterdam, The Netherlands, 2004.

50. Ayuob, N.N.; Abdel-Tawab, H.S.; El-Mansy, A.A.; Ali, S.S. The protective role of musk on salivary glands of mice exposed to chronic unpredictable mild stress. J. Oral. Sci. 2019, 61, 95-102. [CrossRef] [PubMed]

51. Shi, Z.; Rockey, D.C. Upregulation of the actin cytoskeleton via myocardin leads to increased expression of type 1 collagen. Lab. Investig. 2017, 97, 1412-1426. [CrossRef] [PubMed]

52. Alali, Z.; Graham, A.; Swan, K.; Flyckt, R.; Falcone, T.; Cui, W. 60S acidic ribosomal protein P1 (RPLP1) is elevated in human endometriotic tissue and in a murine model of endometriosis and is essential for endometriotic epithelial cell survival in vitro. Mol. Hum. Reprod. 2020, 26, 53-64. [CrossRef]

53. Sisto, M.; Lisi, S. The role of the epithelial-to-mesenchymal transition (EMT) in diseases of the salivary glands. Histochem. Cell Biol. 2018, 150, 133-147. [CrossRef] 
54. Takahashi-Horiuchi, Y.; Sugiyama, K.; Sakashita, H.; Amano, O. Expression of heat shock protein 27 with the transition from proliferation to differentiation of acinar precursor cell in regenerating submandibular gland of rats. Tohoku J. Exp. Med. 2008, 214, 221-230. [CrossRef]

55. Porcheri, C.; Mitsiadis, T.A. Physiology, Pathology and Regeneration of Salivary Glands. Cells 2019, 8, 976. [CrossRef]

56. Amano, O.; Mizobe, K. Anatomy and histology of rodent and human major salivary glands-Overview of the japan salivary gland society-sponsored workshop. Acta Histochem. Cytochem. 2012, 45, 241-250. [CrossRef] [PubMed]

57. Council, N.R. Guide for the Care and Use of Laboratory Animals, 8th ed.; The National Academies Press: Washington, DC, USA, 2011.

58. Percie du Sert, N.; Hurst, V.; Ahluwalia, A.; Alam, S.; Avey, M.T.; Baker, M.; Browne, W.J.; Clark, A.; Cuthill, I.C.; Dirnagl, U.; et al. The ARRIVE guidelines 2.0: Updated guidelines for reporting animal research. PLoS Biol. 2020, 18, e3000410.

59. Amado, L.L.; Garcia, M.L.; Ramos, P.B.; Freitas, R.F.; Zafalon, B.; Ferreira, J.L.R.; Yunes, J.S.; Monserrat, J.M. A method to measure total antioxidant capacity against peroxyl radicals in aquatic organisms: Application to evaluate microcystins toxicity. Sci. Total Environ. 2009, 407, 2115-2123. [CrossRef]

60. Esterbauer, H.; Cheeseman, K.H. Determination of aldehydic lipid peroxidation products: Malonaldehyde and 4-hydroxynonenal. Methods Enzymol. 1990, 186, 407-421. [PubMed]

61. Dionizio, A.S.; Melo, C.G.S.; Arias-Sabino, I.T.; Ventura, T.M.S.; Leite, L.A.; Souza, S.R.G.; Santos, E.X.; Heubel, A.D.; Souza, J.G.; Perles, J.V.C.M.; et al. Chronic treatment with fluoride affects the jejunum: Insights from proteomics and enteric innervation analysis. Sci. Rep. 2018, 8, 3180. [CrossRef] [PubMed]

62. Bradford, M.M. A rapid and sensitive method for the quantitation of microgram quantities of protein utilizing the principle of protein-dye binding. Anal. Biochem. 1976, 72, 248-254. [CrossRef]

63. Lima-Leite, A.; Lobo, J.G.V.M.; Pereira, H.A.B.S.; Fernandes, M.S.; Martini, T.; Zucki, F.; Sumida, D.H.; Rigalli, A.; Buzalaf, M.A.R. Proteomic analysis of gastrocnemius muscle in rats with streptozotocin-induced diabetes and chronically exposed to fluoride. PLOS ONE 2014, 9, e106646.

64. Bindea, G.; Mlecnik, B.; Hackl, H.; Charoentong, P.; Tosolini, M.; Kirilovsky, A.; Fridman, W.H.; Pagès, F.; Trajanoski, Z.; Galon, J. ClueGO: A Cytoscape plug-in to decipher functionally grouped gene ontology and pathway annotation networks. Bioinformatics 2009, 25, 1091-1093. [CrossRef]

65. R Development Core Team. R: A Language and Environment for Statistical Computing. 2013. Available online: https://www. gbif.org/tool/81287/r-a-language-and-environment-for-statistical-computing (accessed on 11 November 2021).

66. Alhamdoosh, M.; Ng, M.; Wilson, N.J.; Sheridan, J.M.; Huynh, H.; Wilson, M.J.; Ritchie, M.E. Combining multiple tools outperforms individual methods in gene set enrichment analyses. Bioinformatics 2017, 33, 414-424. [CrossRef]

67. Shannon, P.; Markiel, A.; Ozier, O.; Baliga, N.S.; Wang, J.T.; Ramage, D.; Amin, N.; Schwikowski, B.; Ideker, T. Cytoscape: A software environment for integrated models of biomolecular interaction networks. Genome Res. 2003, 13, 2498-2504. [CrossRef] [PubMed]

68. Xia, J.; Benner, M.J.; Hancock, R.E.W. NetworkAnalyst-integrative approaches for protein-protein interaction network analysis and visual exploration. Nucleic Acids Res. 2014, 42, W167-W174. [CrossRef] [PubMed]

69. Bohl, L.; Merlo, C.; Carda, C.; Gomez de Ferrari, M.E.; Carranza, M. Morphometric analysis of the parotid gland affected by alcoholic sialosis. J. Oral. Pathol. Med. 2008, 37, 499-503. [CrossRef] [PubMed] 